\title{
Pigment dynamics associated with the grazing of a ciliate and a flagellate feeding on a cyanobacterium
}

\author{
Behzad MOSTAJIR ${ }^{\mathrm{a}^{* \dagger}}$, José BUSTILLOS-GUZMÀN ${ }^{\text {\$\$ }}$, Hervé CLAUSTRE ${ }^{\mathrm{b}}$, \\ Fereidoun RASSOULZADEGAN ${ }^{\text {a }}$
}

\author{
${ }^{a}$ Université Picrre ct Maric Curic, Paris VI, CNRS-URA 716, Station Zoologiquc, B.P. 28, \\ 06230 Villefranche-sur-Mer, France \\ ${ }^{b}$ Université Pierre et Marie Curie, Paris VI, CNRS-INSU, Laboratoire de Physique et Chimie Marines, B.P. 8, \\ 06230 Villefranche-sur-Mer, France \\ * Present address: Institut National de la Recherche Scientifique, INRS - Océanologie, 310, allée des Ursulines, Rimouski, \\ Québec, G5L 3A1, Canada \\ $\S$ Present address: Centro de Investigaciones Biologicas del Noroeste Apartado Postal 128, La Paz Baja California Sur, \\ Mexico 23000
}

(Received 01/08/97, revised 14/05/98, accepted 29/05/98)

\begin{abstract}
The egestion of particulate material as well as pigment degradation during microzooplankton grazing on phytoplankton are poorly known processes. In an attempt to evaluate these processes, changes in pigment concentrations within various size fractions were monitored in batch cultures of an assemblage of a pelagic ciliate (Strombidium sulcatum) and a heterotrophic flagellate (Paraphysomonas sp.) feeding on a cyanobacterium (Synechococcus sp.) over a 10-day period. Chlorophyll $a$, carotenoids and phaeopigments were not found in the $0.1-0.7 \mu \mathrm{m}$ fraction while the pigments originally in the $0.7-3.0 \mu \mathrm{m}$ fraction (prey) were transferred into the $>3.0 \mu \mathrm{m}$ size fraction (predator). During this transfer, the carotenoids (zeaxanthin and B-carotene) were not degraded significantly. In contrast, chlorophyll $a$ was degraded into phaeophytin-like compounds which accounted for almost $100 \%$ of the recorded phaeopigments. The destruction of chlorophyll $a$ varied with time ranging from $4 \%$ (day 3 ) to almost $100 \%$ (end of the experiment) and this destruction was inversely related to micro-grazer ingestion rates. Microscopic examinations of samples did not reveal any large egested particles $>3.0 \mu \mathrm{m}$, suggesting that phaeopigments and carotenoids measured in this size fraction were accumulated inside the protozoa. Zeaxanthin was very stable even when it was within the mico-grazer. (C) Elsevier, Paris
\end{abstract}

pigment / phaeopigment / grazing / protozoa / HPLC

Résumé - Dynamique des pigments associée au broutage des cyanobactéries par un cilié et un flagellé. L'égestion de matériel particulaire et la dégradation des pigments par suite du broutage microhétérotrophe sur le phytoplancton sont des processus peu documentés. Afin de les évaluer, les changements des concentrations pigmentaires dans différentes fractions de taille sont étudiés, sur une période de dix jours, dans des cultures en batch d'un assemblage de cyanobactéries (Synechococcus sp.), de ciliés pélagiques (Strombidium sulcatum) et de flagellés hétérotrophes (Paraphysomonas sp.). Aucun pigment (chlorophylle $a$, caroténoïdes et phéopigments) n'est détecté dans la fraction de taille $0,1-0,7 \mu \mathrm{m}$. Les pigments initialement présents dans la fraction de taille $0,7-3,0 \mu \mathrm{m}$ (proies) ont été transférés vers la fraction $>3,0 \mu \mathrm{m}$ (prédateurs). Pendant le transfert, les caroténoïdes (zéaxanthine et $\beta$-carotène) ne sont pas dégradés de façon significative, alors que la chlorophylle $a$ est dégradée principalement en composés de la famille des phéophytines qui représentent près

\footnotetext{
${ }^{\top}$ Correspondence and reprints
} 
de $100 \%$ des phéopigments. La destruction de la chlorophylle $a$ varie dans le temps de $4 \%$ (jour 3 ) à $100 \%$ (fin de l'expérience). Cette destruction est inversement liée aux taux d'ingestion des micro-brouteurs. L'étude microscopique des échantillons ne montre aucune éjesta particulaire $>3,0 \mu \mathrm{m}$. Cela suggère que les phéopigments et les caroténoïdes mesurés dans cette fraction de taille sont accumulés à l'intérieur de protozoaires. Le zéaxanthine est très stable, même lorsqu'il se trouve à l'intérieur des micro-brouteurs. (C) Elsevier, Paris

\section{pigment / phéopigment / broutage / protozoaire / HPLC}

\section{INTRODUCTION}

Chlorophyll and its degradation products have been proposed as tools for studying feeding activities of herbivorous zooplankton [34], but the validity of these approaches has been questioned, given the variability in the conversion efficiency of chlorophyll into phaeopigments during grazing processes $[6,12,13,21,24]$. The use of HPLC for pigment analysis has opened new fields of research in grazing studies such as the recognition of new pigments and degradation products $[14,26]$ or the use of specific pigment bio-markers for investigation taxa-specific phytoplankton-grazer relationships [4, 30].

The pathways of pigment degradation in aquatic ecosystems are indeed complex and most studies have been concerned with macro-grazers [15]. However, the assessment of microzooplankton grazing activity using phaeopigments is possible [29]. Nagata and Kirchman [22] hypothesised that flagellates release digestive enzymes, incompletely digestcd membranes, and probably other cellular components which come from the prey. Together with the results of studies concerning fecal production by protozoa $[2,3,7,9,23,28]$, it seems possible that there might be pigment bio-markers within egested material of protozoa. In addition, Strom [29] has reported the production of specific phacophorbide $a$-like and phaeophytin a-like compounds by microzooplankton.

Autotrophic populations in oligotrophic systems are dominated by cyanobacteria and prochlorophytes. Such cells, which may comprise up to $70 \%$ of the total chlorophyll biomass [5], are mostly grazed by protozoa. Because of methodological problems, the quantification of grazing activities in natural conditions has received little attention [20]. Although alternative ways of investigating trophic relationships within the microbial food web are potentially possible through the use of pigments and their degradation products as investigative tools, the few investigations dealing with pigment pathways within the microbial food web have been contradictory $([1,19$, 29] see discussion).
In the present investigation, the dynamics and fate of pigments were siudied within a simplified oligotrophic, Mediterranean trophic web. Synechococcus sp. was selected because it is probably an important contributor to the primary production in the Northwestern Mediterranean Sea [11]. The heterotrophic micro-grazers were an oligotrich ciliate, Strombidium sulcatum, and a flagellate, Paraphysomonas sp. Our goals were 1) to determine whether phaeopigments are produced during grazing by microzooplankton and if so, to describe the type of compounds produced, 2) to investigate the respective fates of chlorophyll $a(\mathrm{Chl} a$ ) and carotenoids (zeaxanthin and $B$-carotene), and 3 ) to identify the size classes of particles in which pigments appear during grazing.

\section{MATERIALS AND METHODS}

Ciliates and cyanobacteria were isolated from surface water of the Villefranche-sur-Mer Bay (Station B: $43^{\circ} 41^{\prime}$ $10^{\prime \prime} \mathrm{N}$ and $7^{\circ} 19^{\prime} 00^{\prime \prime} \mathrm{E}$ ). Synechococcus $\mathrm{sp}$. was grown at $22{ }^{\circ} \mathrm{C}$ in $\mathrm{f} / 2$ medium [10] on an 18:6 light:dark cycle. Strombidium s. (approx. $30 \mu \mathrm{m}$ in size) was cultured in the dark on a heterotrophic bacterial diet according to Rivier et al. [27]. The heterotrophic micro-flagellate Paraphysomonas sp. (approx. $5 \mu \mathrm{m}$ in size) was similarly maintained and used as a second micro-grazer.

A time-series experiment ( $10 \mathrm{~d}$ ) was carried out in duplicate in twelve $1 \mathrm{~L}$ conical flasks, each containing $500 \mathrm{~mL}$ of seawater. Initial concentrations of cyanobacteria, ciliates and flagellates were $40 \times 10^{6}$ cells $\mathrm{mL}^{-1}$, 20 cells $\mathrm{mL}^{-1}$ and 50 cells $\mathrm{mL}^{-1}$, respectively. In order to obtain acceptable detection levels of pigments, the concentrations of microorganisms in our experiments were much higher than those normally found in situ. Twelve $50 \mathrm{~mL}$ flasks containing only cyanobacteria $(40 \times$ $10^{6}$ cells $\mathrm{mL}^{-1}$ ), kept under the same conditions were used as controls. All experiments were performed at $22^{\circ} \mathrm{C}$ in the dark. Samples for pigment degradation, phaeopigment production analysis and cell counting were 
collected on days $0,1,3,5,7$ and 10 . For these analyses, the following treatments were applied by harvesting two duplicate flasks: I) Total sample: $100 \mathrm{~mL}$ were filtered through $47 \mathrm{~mm}, 0.7 \mu \mathrm{m}$ glass fiber filters $(\mathrm{GF} / \mathrm{F})$; II) Fraction $0.7-3.0 \mu \mathrm{m}: 250 \mathrm{~mL}$ were filtered by gravity through $47 \mathrm{~mm}, 3.0 \mu \mathrm{m}$ polycarbonate filters, and $100 \mathrm{~mL}$ of the filtrate were re-filtered through $\mathrm{GF} / \mathrm{F}$ filters; III) Fraction $0.1-0.7 \mu \mathrm{m}: 100 \mathrm{~mL}$ of the filtrate passing through GF/F filters were re-filtered through $25 \mathrm{~mm}$, $0.1 \mu \mathrm{m}$ polycarbonate filters; IV) Control : $40 \mathrm{~mL}$ of cyanobacteria were filtered onto GF/F filters. When filtration was not performed by gravity (GF/F and $0.1 \mu \mathrm{m}$ filters), the vacuum pressure was kept low ( $<0.2$ bar). All filters were immediately stored at $-20{ }^{\circ} \mathrm{C}$ prior to pigment analysis. To determine the pigment changes in the $>3.0 \mu \mathrm{m}$, the pigment concentrations in this size fraction were calculated by subtracting the pigment concentrations in the $0.7-3.0 \mu \mathrm{m}$ fraction from those of the total sample. Direct pigment measurement in the $>3.0 \mu \mathrm{m}$ required that the complete sample be filtered through a $3.0 \mu \mathrm{m}$ filter which increased the possibility of protozoan cell bursting and loss of the material. For the same reason, the zeaxanthin to $\mathrm{Chl}$ a ratio was calculated in the $0.7-3.0 \mu \mathrm{m}$ to know whether there was material lost from $>3.0 \mu \mathrm{m}$ to this size fraction.

For ciliate counts, duplicate $2 \mathrm{~mL}$ subsamples were preserved with acid Lugol ( $0.4 \%$ final conc.) and counted according to Rassoulzadegan and Gostan [25] using a Zeiss inverted microscope. For estimating the change in cyanobacterial and flagellate concentrations and also for measuring flagellate diameters ( $\mathrm{n}=20$ in each replicate), $1 \mathrm{~mL}$ of each sample was diluted with $9 \mathrm{~mL}$ of filtered, autoclaved seawater. The samples were fixed with formaldehyde (final conc. $3 \%$ ) and filtered through black Nuclepore polycarbonate membranes $(25 \mathrm{~mm}$ dia., $0.2 \mu \mathrm{m}$ pore) using low vacuum ( $<0.2$ bar). Filters were placed on a slide and examined using a Zeiss Axiophot T/R microscope with epifluorescence equipment, a $3 \mathrm{Fl}$ reflcctor, a DAPI filter set 487902: BP365, FT395, LP420, and a 100X Neofluar objective.

After extraction in $100 \%$ acetone, pigments were analysed using the RP- C8 HPLC method described in Vidussi et al. [32] using an additional LDC spectrophotometer detector $(667 \mathrm{~nm})$ to monitor phaeopigments. Phaeophytin $a$ was identified by comparing the elution time and visible absorption spectrum (obtained with a diode array spectrophotometer) of the appropriate peak with those from an acidified sample of Chl $a$. Unknown phacopig- ments more polar than $\mathrm{Chl} a$ (eluting before $\mathrm{Chl} a$ ) were quantified as if they were phaeophorbide $a$-like pigments, while compounds eluting after $\mathrm{Chl} a$ were quantified as phaeophytin $a$-like pigments. Specific absorption coefficients $\left(667 \mathrm{~nm}\right.$ ) of $50.0 \mathrm{~L} \mathrm{~g}^{-1} \mathrm{~cm}^{-1}$ (phaeophytin $a$ ) and $53.6 \mathrm{~L} \mathrm{~g}^{-1} \mathrm{~cm}^{-1}$ (phaeophorbide $a$-like) were used for phaeopigment quantification.

To perform a budget of Chl a-related compounds (Chl $a$ and phaeopigments), results are expressed in terms of Chl $a$ equivalent (Chl $a \mathrm{cq})$ :

Chl $a \mathrm{eq}=\mathrm{Chl} a+$ Phaeopigments

$\times[(\mathrm{Chl} a \mathrm{MW} /$ Phaeopigment MW) $]$

where MW corresponds to the molecular weight of the pigment considered.

Subtraction of pigment and phaeopigment concentrations in control flasks from those of experimental flasks can lead to an underestimation of ingestion in experiments when large sampling intervals are used. Thus in expcrimental flasks, the average pigment concentration (ng $\mathrm{mL}^{-1}$ ) at any time was determined by calculating specific coefficients of growth and grazing [8] according to Strom [29].

\section{RESULTS}

\subsection{Microbial population dynamics}

Abundances of both heterotrophic flagellates and ciliates increased during the first five days of the experiment (figure 1a). Between days 5 and 7, ciliate density rose while flagellate abundance decreased slightly. During the final part of the experiment (days 7 to 10) both ciliate and flagellate densities decreased. Cyanobacterial concentrations decreased rapidly at the beginning of the experiment, and were minimal from day 5 through to the end of the experiment. Based on microscopic examination during the experiment, cilliates were full of cyanobacteria and they did not prey on flagellates. During our experiments we found the feeding behaviour of Paraphysomonas sp. to be rather unusual. Before grazing, this protozoan was approximately $5 \mu \mathrm{m}$ in diameter but after engulfing cyanobacteria, its cell diameter doubled $(10 \mu \mathrm{m})$. As a result, flagellates made a higher contribution to total grazer biovolume than ciliates (figure $1 b$ ). Ciliate biovolume was estimated to be constant during experiment $\left(13.9 \times 10^{3} \mu \mathrm{m}^{3},[35]\right)$. 


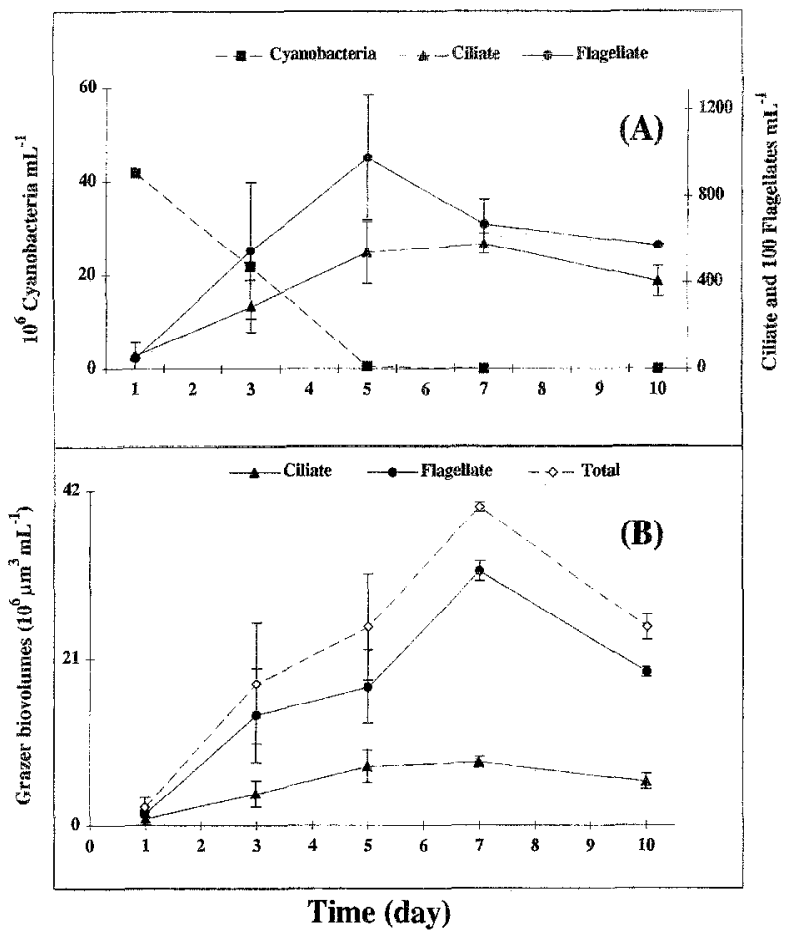

Figure 1. Abundances (cells $\mathrm{mL}^{-1}$ ) of cyanobacteria (Synechococcus sp.), ciliates (Strombidium sulcatum) and heterotrophic flagellates (Paraphysomonas sp.) (A), and grazer biovolume (B) during experimental period in the total sample. Bars represent standard deviations.

\subsection{Conservative pigments}

no pigments were found in the $0.1-0.7 \mu \mathrm{m}$ size fraction. Thercfore, only results from the total sample, the 0.7 $3.0 \mu \mathrm{m}$ and the $>3.0 \mu \mathrm{m}$ fractions are reported. Although prey were removed by grazing during days 1 to 3 and remained minimal until the end of the experiment, zeaxanthin and $B$-carotene concentrations remained practically unchanged (figure $2 a$ ) (mean values not significantly different from initial concentrations; $t$ test, $P=0.05$ ). The total sample contained both cyanobacteria and microzooplankton, while the 0.7-3.0 $\mu \mathrm{m}$ fraction included only cyanobacteria. Carotenoid concentrations in the $0.7-3.0 \mu \mathrm{m}$ fraction decreased with the disappearance of cyanobacteria (figure $2 b$ ). In the $>3.0 \mu \mathrm{m}$ fraction, corresponding to protozoa or perhaps to their fecal material, carotenoids (especially zeaxanthin) increased until day 7 and then remained stable (figure $2 c$ ).

\subsection{Non-conservative pigments}

The decrease of $\mathrm{Chl} a$ concentration in the total sample, from $57 \mathrm{ng} \mathrm{mL} \mathrm{m}^{-1}$ to $15 \mathrm{ng} \mathrm{mL}^{-1}$, paralleled the increase in

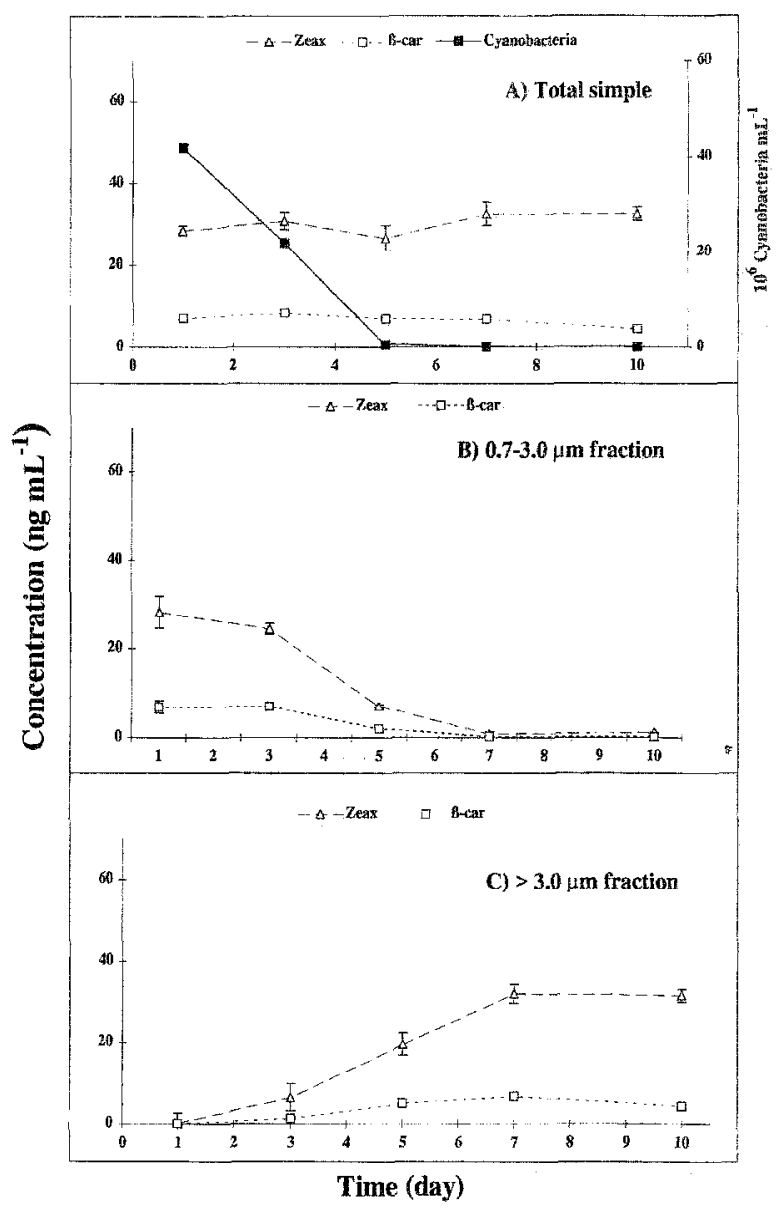

Figure 2. Calculated conservative pigment concentrations, zeaxainthin (Zeax) and $B$-carotene ( $B$-car), in the total sample $(A)$, in the $0.7-3.0 \mu \mathrm{m}$ fraction $(\mathrm{B})$, and $>3.0 \mu \mathrm{m}$ fraction $(C)$. Bars represent standard deviations.

biovolume of the heterotrophic grazers (figures $3 a \mathrm{vs}$. figure $(b)$. Total phaeopigment concentration in the total sample increased from 4 to $20 \mathrm{ng} \mathrm{mL}^{-1}$ between days 3 and 7 , but remained essentially constant thereafter. The Chl $a$ eq concentration as an indicator of Chl $a$ budget in

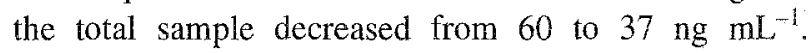
Phaeophorbide $a$-like compounds were found only in trace amounts. In contrast, phaeophytin a-like compounds were constantly produced and represented almost $100 \%$ of total phaeopigments after day 3 (figure 4). Individually, phaeophytin $a$ and two other compounds eluting before and after phaeophytin $a$ were the most abundant by-products, with phaeophytin $a$ representing $50 \%$ to $89 \%$ of total phaeopigments.

Pigment concentrations in the $0.7-3.0 \mu \mathrm{m}$ fraction were roughly similar to those in the total sample until day 3 , 


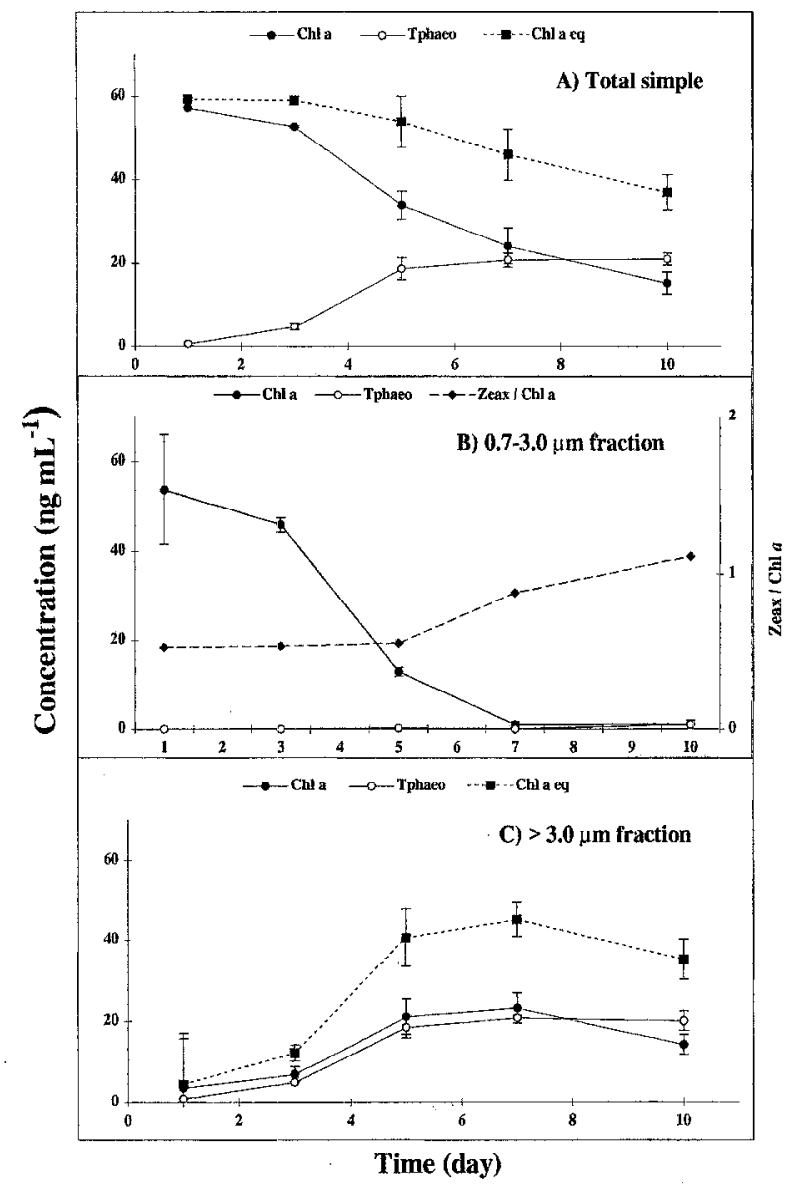

Figure 3. Calculated non-conservative pigment concentrations in the total sannple (A), 0.7-3.0 $\mu \mathrm{m}$ fraction (B), and $>3.0 \mu \mathrm{m}$ fraction (C). Symbols: chlorophyll a (Chla), total phaeopigment (Tphaeo), chlorophyll $a$ equivalent (Chl $a$ eq), and the ratio of zeaxanthin to chlorophyll $a$ (Zeax / Chl a). Bars represent standard deviations.

after which they diminished and became undetectable by day 7 , indicating that pigment consumption became more important aftcr day 3 (figure $3 b$ ). Phaeopigment concentrations were undetectable until day 5 , and only trace amounts were detected by the end of the experimental period $\left(<2 \mathrm{ng} \mathrm{mL} \mathrm{m}^{-1}\right)$. Since experiments were conducted in the dark (after cyanobacteria had been cultured in light), a decrease of the zeaxanthin to $\mathrm{Chl} a$ ratio due to photoadaptation would be expected $\lceil 17\rceil$ in the fraction corresponding to cyanobactera $(0.7-3.0 \mu \mathrm{m})$. This was not the case as this ratio increased from 0.5 to 1.1 (figure $3 b$ ), suggesting that some material, preferentially enriched in zeaxanthin and originating from the detritus or bursting of protozoa, passed through the $3.0 \mu \mathrm{m}$ filter. Moreover, the uncoupling of $\mathrm{Chl} a$ concentration in the

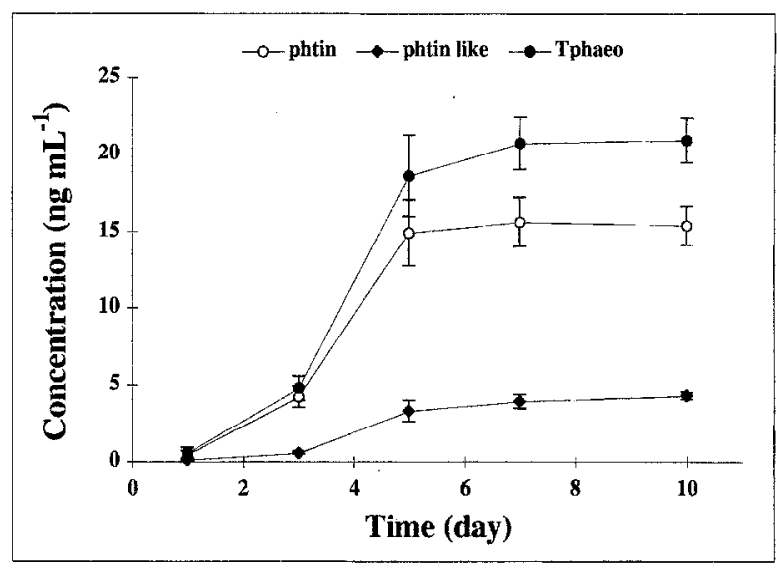

Figure 4. Time-course-changes in concentrations and composition of phaeopigment in the total sample. Symbols: total phaeopigment (Tphaeo), phaeophytin $a$ (phtin), and phaeophytin $a$ like (phtin like). Bars represent standard deviations.

0.7-3.0 $\mu \mathrm{m}$ fraction and cyanobacterial abundance (figure $3 b$ vs figure $l a$ ) could be the result of such enrichment of this fraction by the $>3.0 \mu \mathrm{m}$ fraction.

In the $>3.0 \mu \mathrm{m}$ fraction, Chl $a$ and total phaeopigment concentrations increased until days 5 and 7 . A decrease of $\mathrm{Chl} a$ concentration at the end of the experiment coincided with an increase of total phaeopigment concentration. The Chl $a$ eq concentration in this fraction increased 8 -fold during the experiment whereas in the total sample the Chl $a$ eq concentration decreased 1.6-fold.

\subsection{Chl $a$ destructions and protozoan ingestion rates}

In order to relate the degree of destruction of $\mathrm{Chl} a$ to protozoan ingestion rate (as reported for copepods [16, 24]), and to consider changes in biovolume of heterotrophs, ingestion rates were calculated as follows and shown in figure 5:

In $=\left[\left(C_{t+1}-C_{t}\right) /\left(B V_{t+1}-B V_{t}\right)\right] /\left(t_{+1}-t\right)$, wherc:

In $=$ ingestion rate $\left(\mathrm{nb}\right.$ cyanobacteria $\left.\mu \mathrm{m}^{-3} \mathrm{~h}^{-1}\right)$

$\mathrm{C}=$ cyanobacterial $\mathrm{mL}^{-1}$

$\mathrm{BV}=$ biovolume of heterotrophic protozoa $\left(\mu \mathrm{m}^{3} \mathrm{~mL}^{-1}\right)$

$\mathrm{t}=$ time $(\mathrm{h})$

Results demonstrated that the highest $\mathrm{Chl} a$ destruction occurred at the end of the experiment when protozoan ingestion rates were lowest (figure 5). 


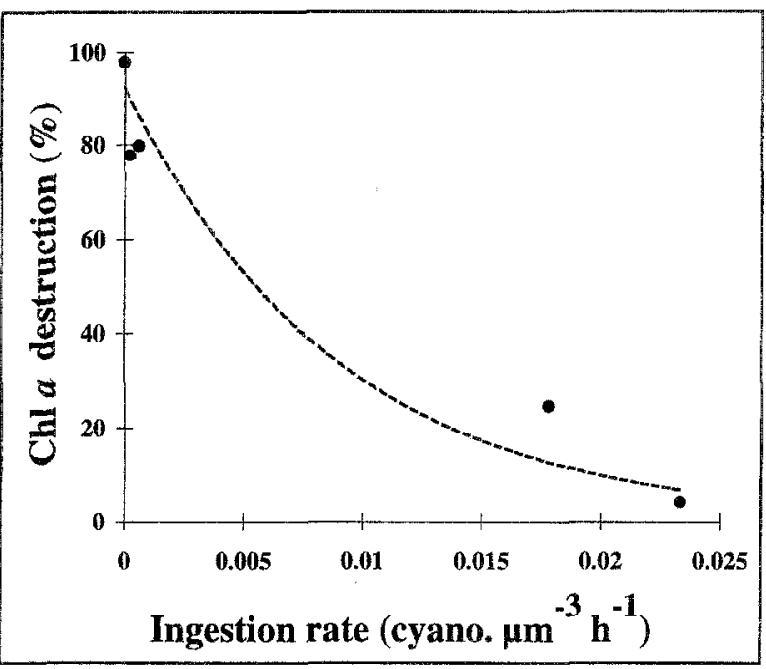

Figure 5. Chlorophyll $a$ destruction as a function of ingestion rate of microzooplankton (assemblage of ciliate and flagellate) feeding on cyanobacteria.

\section{DISCUSSION}

Pigment metabolism and phaeopigment production resulting from protozoan grazing have been poorly studied. Moreover, the qualitative and quantitative results existing in this domain are contradictory. Klein et al. [19] and Barlow et al. [1] found that only $5 \%$ of the Chl ingested by the heterotrophic dinoflagellate Oxyrrhis marina was converted to phaeophytin, and that carotenoids disappeared completely. In contrast, Strom [29] showed significant production of several phaeophorbide and phaeophytin-like compounds by marine protozoa and hypothesised that re-ingestion of fecal material could lead to extensive pigment destruction.

Our results show that phaeopigment concentrations were not detectable in the $0.1-0.7 \mu \mathrm{m}$ size fraction and only trace amounts were found in the $0.7-3.0 \mu \mathrm{m}$ size fractions. However, large amounts of phaenpigments appeared in the $>3.0 \mu \mathrm{m}$ fraction (figure $3 \mathrm{c}$ ). These results suggest that the egested material containing phaeopigments was $<0.1 \mu \mathrm{m}$ or $>3.0 \mu \mathrm{m}$, or that the phaeopigments in the $>3.0 \mu \mathrm{m}$ fraction were actually in the protozoa. The first possibility could correspond to the soluble phase of phaeopigment. According to Klein et al. [19], degraded material does not contain pigments in the $<0.7 \mu \mathrm{m}$ size fraction. However, Tranvik et al. [31] have shown that even colloidal dissolved organic material can be taken up and used by heterotrophic flagellates. Thus, according to Strom's hypothesis, phaeopigments in this study might have been egested by protozoa into the dissolved phase, and then consumed almost immediately after egestion. Little is known concerning this process for protozoa but we believe it unlikely that the phaeopigments in our experiment would have been found in the $<0.1 \mu \mathrm{m}$ fraction. Since epifluorescence microscopic examination using blue and green filters did not show any large egested particles $(>3.0 \mu \mathrm{m})$, it seems that the phaeopigments in this study must have been accumulated inside the protozoa due to increasing grazer biovolume. Moreover, Chl $a$ eq concentration at the end of the experiment in the total sample $\left(37 \mathrm{ng} \mathrm{mL} \mathrm{m}^{-1}\right)$ was almost the same as the amount found in the $>3.0 \mu \mathrm{m}$ size fraction ( $35 \mathrm{ng} \mathrm{mL}{ }^{1}$ ). This suggests that almost all $\mathrm{Chl} a$ degradation and phaeopigment production processes occurred in the $>3.0 \mu \mathrm{m}$ size fraction. However, the phaeopigments were not released as particulate egested material but rather were accumulated inside the protozoa. Our experimental results agree partially with Strom's hypothesis (phaeopigment production) but they do not suggest re-ingestion or egestion of fecal particles [29]. The differences between our results and those of Strom [29] might be explained by inter-species differences in pigment degradation or the possible effects of feeding history and food concentration, as noted for metazoan grazers [14, 18, 24]. We mentioned earlier the unusual Paraphysomonas sp. behaviour of engulfing cyanobacteria that may partially explain the pigment preservation that we found. Our microscopic examination showed that there were intact cyanobacteria inside the flagellate at the end of the experiment. Likewise, Waterhouse and Welschmeyer [33] suggested recently that $\sim 48 \%$ of the Chl $a$ ingested during their experiments remained intact during protozoan grazing. According to figure 5, microzooplankton destroy less Chl $a$ at their highest ingestion rate (between day 1 and 3) with only $4 \%$ of $\mathrm{Chl} a$ ingested destroyed. This minor $\mathrm{Chl} a$ destruction suggest that protozoa were not efficient in converting $\mathrm{Chl} a$ into colorless products. In contrast, the destruction of $\mathrm{Chl} a$ increased during the experiment as the ingestion rate decreased. It should be noted that the ingestion rate after day 5 was low because there were few cyanobacteria remaining outside the protozoa. During that time, the near complete ingestion of cyanobacteria by the protozoa resulted in more than $78 \%$ destruction of $\mathrm{Chl} a$ into colourless products.

Zeaxanthin is found in cyanobacteria and prochlorophytes, organisms that are in the $<1 \mu \mathrm{m}$ size range. However, zeaxanthin has been recorded in fractions $>3 \mu \mathrm{m}$ in 
the sub-equatorial Pacific (Claustre, unpublished), suggesting that this pigment can also accumulate in situ in the micro-grazer pool, as observed in the present laboratory investigation. Nevertheless, our study was conducted in the dark as were those of Strom [29] and Waterhouse and Welschmeyer [33]. Under light conditions, degradation rates of carotenoids might be suspected to be higher than in the dark as demonstrated by Klein et al. [19]. Therefore, before using zeaxanthin, the autotrophic prokaryote pigment, as an in situ marker of grazing processes, its degradation rate (by other protozoan species and under light conditions) has to be elucidated.

Finally, our results demonstrate that, in contrast to zeaxanthin, phaeopigments cannot be considered as potential markers of protozoan grazing. Increases in phaeophytin $a$ in parallel to $\mathrm{Chl} a$ losses were restricted to only the first days of the experiment. Furthermore, phaeophytin is not specific to microzooplankton and can also be produced by macro-grazers [15].

\section{Acknowledgments}

The authors thank Pr. A. Mignot (University of Clermont-Ferrand) for the identification of the heterotrophic flagellates (Paraphysomonas sp) used in this work. Financial support was provided by the CNRS/INSU (URA 716 and 353), E.E.C. MAST II- MTP (Mediterranean Targeted Programme, contract MAST II-CT930063, Medipelagos), E.E.C. MAS III-CT96-0051 (Mater, Work 504) and Consejo Nacional de Ciencia y Tecnologiá (México) grant to J. B-G.

\section{REFERENCES}

[1] Barlow R.G., Burkill P.H., Mantoura R.F.C., Grazing degradation of algal pigments by marine protozoan Oxyrrhis marina, J. Exp. Mar. Bioll. Ecol. 119 (1988) 119-129.

[2] Buck K.B., Bolt P.A., Garrison D.L., Phagotrophy and fecal pellet production by an athecate dinoflagellate in Antarctic Sea ice, Mar. Ecol. Prog. Ser. 60 (1990) 75-84.

[3] Buck K.R., Newton J., Fecal pellet flux in Dabob Bay during a diatom bloom: Contribution of microzooplankton, Limnol. Oceanogr. 40 (1995) 306-315.

[4] Burkill P.H., Mantoura R.F.C., Llewellyn C.A., Owens N.J.P., Microzooplankton grazing and selectivity of phytoplankton in coastal waters, Mar. Biol. 93 (1987) 581-590.

[5] Claustre H., Marty J.-C., Specific phytoplankton biomasses and their relation to primary production in the tropical north Pacific, Deep-Sea Res. 42 (1995) 1475-1493.

[6] Conover R.J., Durvasula R., Roy S., Wang R., Probable loss of chlorophyll derived pigments during passage through the gut of zooplankton, and some of the consequences, Limnol. Oceanogr. 31 (1986) 878-887.

[7] Elbrächter M., Faeces production by dinoflagellates and other small flagellates, Mar. Microb. Food Webs, 5 (1991) 189-204.

[8] Frost B.W., Effects of size and concentration of food particles on the feeding behaviour of the marine planktonic copepod Calanus pacificus, Limnol. Oceanogr. 17 (1972) 805-815.

[9] González H.E., Distribution and abundance of minipellets around the Antarctic peninsula, Implications for protistan feeding behaviour, Mar. Ecol. Prog. Ser. 90 (1992) 223-236.

[10] Guillard R.R.L., Culture of phytoplankton for feeding marine invertebrates, in: Culture of Marine Invertebrate Animals, W.L.Smith and M.H. Chanley, editors, Plenum, New York, 1975 (1975) $338 \mathrm{p}$.
[11] Hagström A., Azam F., Andersson A., Wikner J., Rassoulzadegan F., Microbial loop in an oligotrophic pelagic marine ecosystem: possible roles of cyanobacteria and nanoflagellates in the organic fluxes, Mar. Ecol. Prog. Ser., 49 (1988) 171-178.

[12] Head E.J.H., Copepod feeding behavior and the measurement of grazing rates, in: Boxshall and Schminke (Eds.). Biology of copepods, Hydrobiologia 167/168 (1988) 31-41.

[13] Head E.J.H., Gut pigment accumulation and destruction by arctic copepods in vitro and in situ, Mar. Biol. 112 (1992) 583-592.

[14] Head E.J.H., Harris L.R., Chlorophyll and carotenoid transformation and destruction by Calanus spp. grazing on diatoms, Mar. Ecol. Prog. Ser. 86 (1992) 229-238.

[15] Head E.J.H., Harris L.R., Feeding selectivity by copepods grazing on natural mixtures of phytoplankton determinated by HPLC analysis of pigments, Mar. Ecol. Prog. Ser 110 (1994) $75-83$.

[16] Head E.J.H., Harris L.R., Chlorophyll destruction by Calanus spp. grazing on phytoplankton: kinetics, effects of ingestion rate and fecding hisrory, and a mechanistic interprctation, Mar. Ecol. Prog. Ser. 135 (1996) 223-235.

[17] Kana T.M., Glibert P.M., Zeaxanthin and B-carotene in Synechococcus WH7803 respond differently to irradiance, Limnol. Oceanogr 33 (1988) 1623-1626.

[18] Kiorbe T., Tiselius P.T., Gut clearance and pigment destruction in a herbivorous copepod, Acartia tonsa, and the determination ins situ grazing rates, J. Plankton Res. 9 (1987) 525-534.

[19] Klein B., Gieskes W.W.C., Kraay G.G., Digestion of chlorophylls and carotenoids by the marine protozoan Oxyrrhis marina studied by h.p.l.c. analysis of algal pigments, J. Plankton Res. 8 (1986) 827-836. 
[20] Landry M.R., Methods and controls for measuring the grazing impact of planktonic protists, Mar. Microb. Food Webs 8 (1994) $37-57$.

[21] Lopez M.D.G., Huntley M.E., Sykes P.F., Pigment destruction by Calanus pacificus: impact on the estimation of water column fluxes, J. Plankton Res. 10 (1988) 715-734.

[22] Nagata T., Kirchman D.L., Release of macromolecular organic complexes by heterotrophic marine flagellates, Mar. Ecol. Prog. Ser. 83 (1992) 233-240.

[23] Nöthig E.M., Bodungen B.V., Occurrence and vertical flux of faecal pellets of probably protozoan origin in the southeastern Weddell Sea ( Antarctica), Mar. Ecol. Prog. Ser. 56 (1989) 281-289.

[24] Penry D.L., Frost B.W., Chlorophyll a degradation by Calanus pacificus: dependence on ingestion rate and digestive acclimation to food resources, Limnol. Oceanogr. 36 (1991) 147-159.

[25] Rassoulzadegan F., Gostan J., Répartition des ciliés pélagiques dans les eaux de Villefranche-sur-mer. Remarques sur la dispersion du microzooplancton en mer et à l'intérieur des échantillons dénombrés par la méthode d'Utermöhl, Ann. Inst. Ocćanogr. 52 (1976) 175-188.

[26] Repeta D.J., Gagosian R.B., Carotenoid diagenesis in recent marine sediment-I, The Pern continental shelf $\left(15^{\circ} \mathrm{S}, 75^{\circ} \mathrm{W}\right)$, Geochim. Cosmochim. Acta 51 (1987) 1001-1009.

[27] Rivier A., Brownlee D.C., Sheldon R.W., Rassoulzadegan F., Growth of microzooplankton: a comparative study of bactivorous zooflagellates and ciliates, Mar. Microb. Food Webs 1 (1985) 51-60.
[28] Stoecker D.K., Particle production by planktonic cillates, Limnol. Oceanogr: 29 (1984) 930-940.

[29] Strom S.L., Production of phaeopigments by marine protozod: results of laboratory experiments analyzed by HPLC, DeepSea Res. 40 (1993) 57-80.

[30] Strom S.L., Welschmeyer N.A., Pigment-specific rates of phytoplankton growth and microzooplankton grazing in the open subartic Pacific Ocean, Limnol. Oceanogr. 36 (1991) 50-63.

[31] Tranvik L.J., Sherr E.B., Sherr B.F., Uptake and utilization of 'colloidal DOM' by heterotrophic flagellates in seawater, Mar. Ecol. Prog. Ser. 92 (1993) 301-309.

[32] Vidussi F., Claustre H., Bustillos-Guzmán J., Marty J.C., Determination of chlorophylls and carotenoids of marine phytoplankton: separation of chlorophyll a from divinyl-chlorophyll a and zeaxanthin from Iutein, I. Plankton Res. 18 (1996) 2377-2382.

[33] Waterhouse T.Y., Welschmeyer N.A., Taxon-specific analysis of microzooplankton grazing rates and phytoplankton growth rates, Limnol. Oceanogr. 40 (1995) 827-834.

[34] Welschmeyer N.A., Lorenzen C.J., Chlorophyll budgets: zooplankton grazing and phytoplankton growth in a temperate fjord and the central Pacific gyres, Limnol. Oceanogt 30 (1985) $1-21$.

[35] Wiadnyana N.N., Rassoulzadegan F., Selective feeding of Acartia clausi an Centropages typicus on microzooplankton, Mar. Ecol. Prog. Ser. 53 (1989) 37-45. 